Provided for non-commercial research and education use. Not for reproduction, distribution or commercial use.

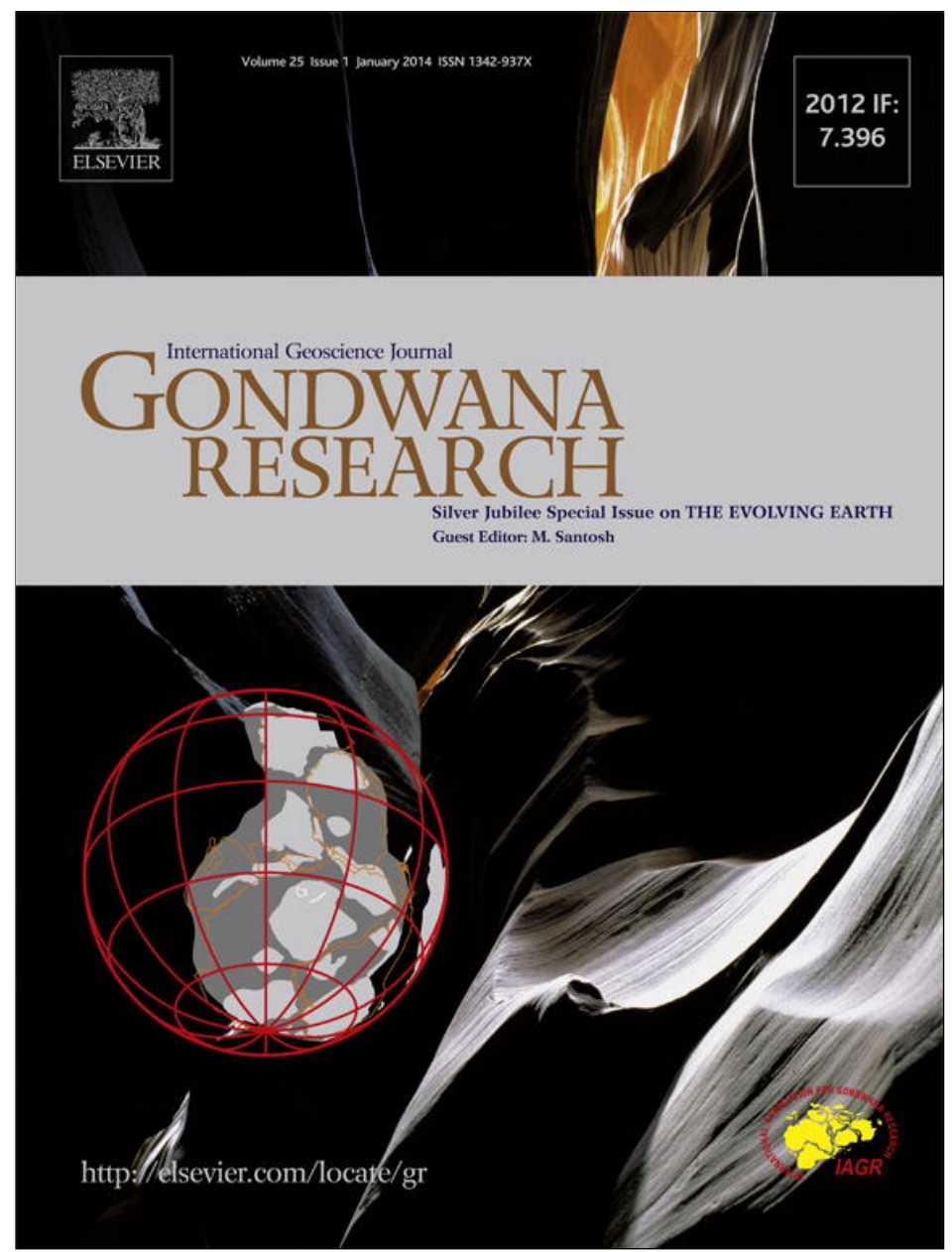

This article appeared in a journal published by Elsevier. The attached copy is furnished to the author for internal non-commercial research and education use, including for instruction at the authors institution and sharing with colleagues.

Other uses, including reproduction and distribution, or selling or licensing copies, or posting to personal, institutional or third party websites are prohibited.

In most cases authors are permitted to post their version of the article (e.g. in Word or Tex form) to their personal website or institutional repository. Authors requiring further information regarding Elsevier's archiving and manuscript policies are encouraged to visit:

http://www.elsevier.com/authorsrights 


\title{
New aeromagnetic view of the geological fabric of southern Dronning Maud Land and Coats Land, East Antarctica
}

\author{
Matthias Mieth*, Wilfried Jokat \\ Alfred-Wegener-Institute (AWI), Columbusstrasse, D-27568 Bremerhaven, Germany
}

\section{A R T I C L E I N F O}

\section{Article history:}

Received 3 November 2012

Received in revised form 3 April 2013

Accepted 4 April 2013

Available online 19 April 2013

Handling Editor: A.R.A. Aitken

\section{Keywords:}

Aeromagnetic

Dronning Maud Land

Coats Land

East Antarctica

Gondwana Suture

\begin{abstract}
A B S T R A C T
The ice shield of Antarctica, which measures several kilometers in thickness, presents a challenge when attempting to unravel the subglacial geology. Here, we report about systematic airborne magnetic surveys conducted over the last decade, which investigated a significant part of Dronning Maud Land (DML), imaging for the first time the crustal architecture of the interior of this sector of East Antarctica. High-resolution data reveal parallel, elongated magnetic anomalies in southeastern DML. These NW-SE trending anomalies can be traced farther east into sparser Russian magnetic data sets. Several high amplitude magnetic anomalies with values above $400 \mathrm{nT}$ have been observed in southwestern DML and Coats Land. They differ clearly in wavelength and amplitudes from the magnetic pattern found in the east and do not show any evidence of a Pan-African orogenic belt or suture zone connecting the Shackleton Range with eastern DML, as hypothesized in several studies. This leads to the assumption of the existence of a hitherto unrecognized large tectonic province in southeastern DML. Whereas an over $100 \mathrm{~km}$ long magnetic lineament in the interior of the Dronning Maud Land may reflect a major shear zone akin to the Pan-African age Heimefrontfjella shear zone. Both findings bring new evidences to the still open question about the amalgation of East and West Gondwana. In addition, the magnetic data allow mapping the eastern extent of the presumable cratonic province of Coats Land, a region considered as a key piercing point for reconstructions of Rodinia. Furthermore, the Beattie Magnetic Anomaly in southern Africa is assumed to continue into East Antarctica. Two magnetic highs in western DML are identified as possible eastward continuation of this prominent anomaly.

(c) 2013 International Association for Gondwana Research. Published by Elsevier B.V. All rights reserved.
\end{abstract}

\section{Introduction}

East Antarctica represents the central puzzle piece in the attempt to reconstruct Gondwana, containing continental fragments of both Eastand West-Gondwana, and our study area Dronning Maud Land (DML) is somehow located in between. The exposed rocks of DML show a Pan African ( 650-490 Ma) metamorphic reworking, except for the most western part, which consist of Archaean ( $>2.5 \mathrm{Ga})$ and undeformed Grenvillian ( $1.1 \mathrm{Ga}$ ) basement rocks (see review by Boger, 2011 and references therein). Therefore, the Antarctic part of the suture zone between East- and West-Gondwana is supposed to be located somewhere in DML (Fig. 1, blue dashed lines), either as an extension of the Mozambique belt (Moyes et al., 1993; Shiraishi et al. 1994; Grunow et al., 1996; Shackleton, 1996) forming a continuous East African-Antarctic orogen (Jacobs et al., 1998), as a curvilinear continuation of the Kuunga suture (Boger and Miller, 2004), or as a combination of both (Kleinschmidt and Boger, 2009). The variety of models exists because most of the geology is not accessible to direct sampling due to the extensive ice coverage. Hence, aero-geophysical data play a

\footnotetext{
* Corresponding author. Tel.: + 4947148311866.

E-mail address: Matthias.Mieth@awi.de (M. Mieth).
}

key role in extrapolating the sparse geological information into the interior of East Antarctica for purposes of developing a reliable tectonic model. Several onshore aeromagnetic surveys (Golynsky et al., 1996, 2002; Damaske et al., 2005; Ferraccioli et al., 2005a, 2005b; Shepherd et al., 2006; Riedel et al., 2013) were conducted in DML to better constrain and understand the Gondwana pre-break-up geology (older than $180 \mathrm{Myr}$ ). In this context, an important discovery by Riedel et al. (2013) identified, among other magnetic anomalies, a linear NE-SW trending anomaly in central DML (Fig. 1, gray area (6): Forster Magnetic Anomaly), which might represent the suture zone of the East African-Antarctic orogen in Antarctica (Riedel et al., 2013). Since 2008 subsequent surveys constantly densified the magnetic data set in the unexplored southern DML (Fig. 2-inlay, red lines). The latest compilation of this larger data set is subject of this contribution, including a hitherto unpublished data set over eastern Coats Land, providing new insights about the tectonic fabric of southern DML. The analysis of our data supports not only the conclusion of Riedel et al. (2013) about the location of the E-W Gondwana suture zone in DML and identifies its possible continuation, but also indicating that the interior of East Antarctica is not comprised of one stable craton but rather of a mosaic of different crustal fragments. The latter will be of interest for studies of both the Gondwana and the Rodinia assembly. 


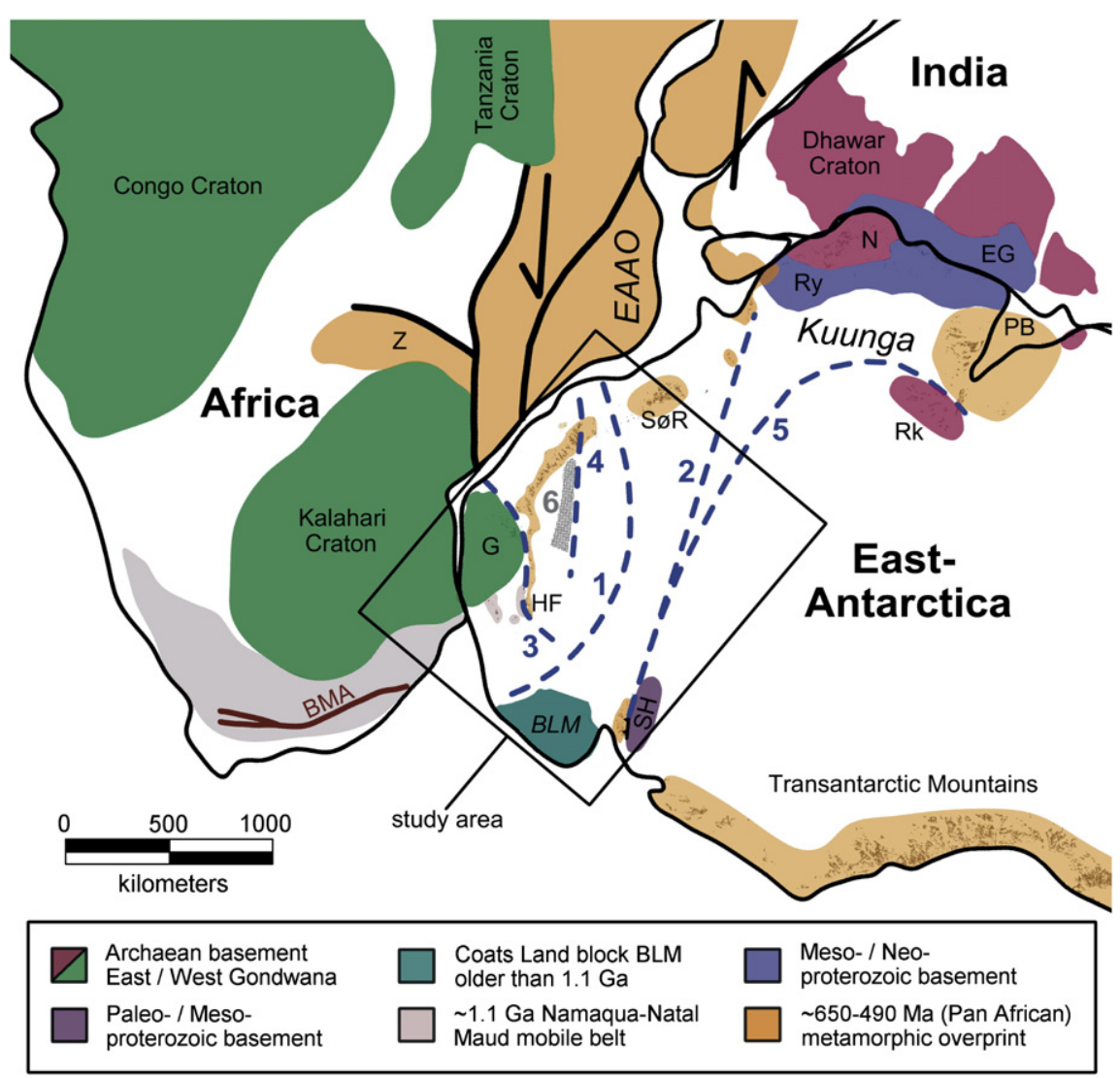

Fig. 1. Geological setting of the study area within Gondwana at $500 \mathrm{Ma}$. The simplified sketch is adapted from Jacobs and Thomas (2004) and Helferich et al. (2004). Blue dashed lines showing hypothesized traces of the E-W Gondwana suture: 1 - Moyes et al. (1993), 2 - Grunow et al. (1996), 3 - Shackleton (1996), 4 - Jacobs et al. (1998), and between East Antarctica and W-Gondwana: 5 - Kleinschmidt and Boger (2009). The gray area (6) marks the Forster Magnetic Anomaly interpreted as suture by Riedel et al. (2013). The East African orogen is assumed to continue into Antarctica forming one orogen (EAAO), while the term Kuunga is used for collision of India and East Antarctica. Abbreviations: BLM - Betrab-Littlewood-Molke province (Coats Land block), BMA - Beattie Magnetic Anomaly, EAAO - East African Antarctic orogen, EG - Eastern Ghats, G - Grunehogna craton, HF - Heimefrontfjella, N - Napier, PB - Prydz Bay, Rk - Ruker craton, Ry - Rayner, SH - Shackleton Range, SøR - Sør Rondane, Z - Zambezi belt.

\section{Geological setting}

Very little is known about the geology of the ice-covered interior of DML since all outcrops are located at the northern rim of the area of interest. The prominent Archaean Grunehogna province is located in the NW of DML (Fig. 1, G). Prior to the Gondwana break-up ( 180 Ma), this craton was juxtaposed to the Kaapvaal craton in southern Africa (e.g., Martin and Hartnady, 1986; Leinweber and Jokat, 2012). The low-grade sedimentary and volcanogenic rocks of the Ritscherflya Supergroup overlay the Archaean basement in the eastern part of the Grunehogna province. These Mesoproterozoic rocks are intruded by tholeiitic sills and dykes (Wolmarans and Kent, 1982), interpreted as part of the Umkondo large igneous province (LIP) and are linked to coeval LIPs in Laurentia (Hanson et al., 1998, 2004), supporting the SWEAT hypothesis (Moores, 1991). The area of the Borgmassiv is associated with magnetic high frequency anomalies of medium amplitudes up to $150 \mathrm{nT}$ (Ferraccioli et al., 2005b).

A Grenvillian $(\sim 1.1 \mathrm{Ga})$ collision belt named Namaqua-Natal-Maud fringes around the Kaapvaal-Grunehogna craton (e.g. Jacobs et al., 1998). It is commonly interpreted to be formed by an juvenile island arc, but Grosch et al. (2007) concluded from isotopic data and geochemical characteristics that at least the Maud belt in Antarctica was once an active continental volcanic arc, thereby neglecting the existence of a major Grenvillian crustal suture between both provinces. The eastern part of the Maud belt underwent a metamorphic overprint of Pan-African ages ( 560-490 Ma). The main shear zone at Heimefrontfjella (Fig. 1, HF), separating the metamorphic overprinted rocks in the east from non-overprinted rocks in the west, represents a major tectonic feature, as the entire Grenvillian basement of central DML shows Pan-African metamorphic reworking and, hence, is regarded as the western front of the East African-Antarctic orogen (Golynsky and Jacobs, 2001). Perritt and Watkeys (2003) suggested that an unknown block east of western DML moved NNW with respect to the Grunehogna craton, leading to shearing and escape tectonics in a compressional regime in western DML. Jacobs and Thomas (2004) presented a lateral-escape tectonic model for the southern termination of the East African-Antarctic orogen, thus explaining the origin of the microplates Falkland Island, Ellsworth-Haag and Filchner blocks (not shown in Fig. 1), and suggesting that the exposed Heimefront shear zone is just one of several shear zones in western DML. Pan African events in central DML can be differentiated into two stages, an early compressional phase $(560-550 \mathrm{Ma})$ and a subsequent dilational phase (530-490 Ma), whereas the latter phase is associated with voluminous intrusions of post tectonic granotoids and interpreted as a time of orogenic collapse (Jacobs et al., 2003).

The deep Jutul-Penck graben system (up to $1000 \mathrm{~m}$ b.s.l.) is located at the eastern rim of the Grunehogna Province and continues westward as well as southward through the Maud belt (Fig. 4, JP). This graben system is most likely a failed rift system of Jurassic age (Grantham and Hunter, 1991). Both flanks of the graben contain Jurassic dolerite dikes and basalts, which erupted some $\sim 183 \mathrm{Ma}$ as part of the Karoo LIP (e.g. Harris et al., 1990) as well as Jurassic alkaline intrusions, which can be associated with a number of complex magnetic positive anomalies, while a prominent magnetic low over the Jutul graben indicate either an amagmatic rift or thick subglacial sediments (Ferraccioli et al., 2005b; Riedel et al., 2013).

Our dataset covers some poor studied outcrops like the Steingarden nunataks between the Wohlthat Massif in central DML and Sør Rondane 


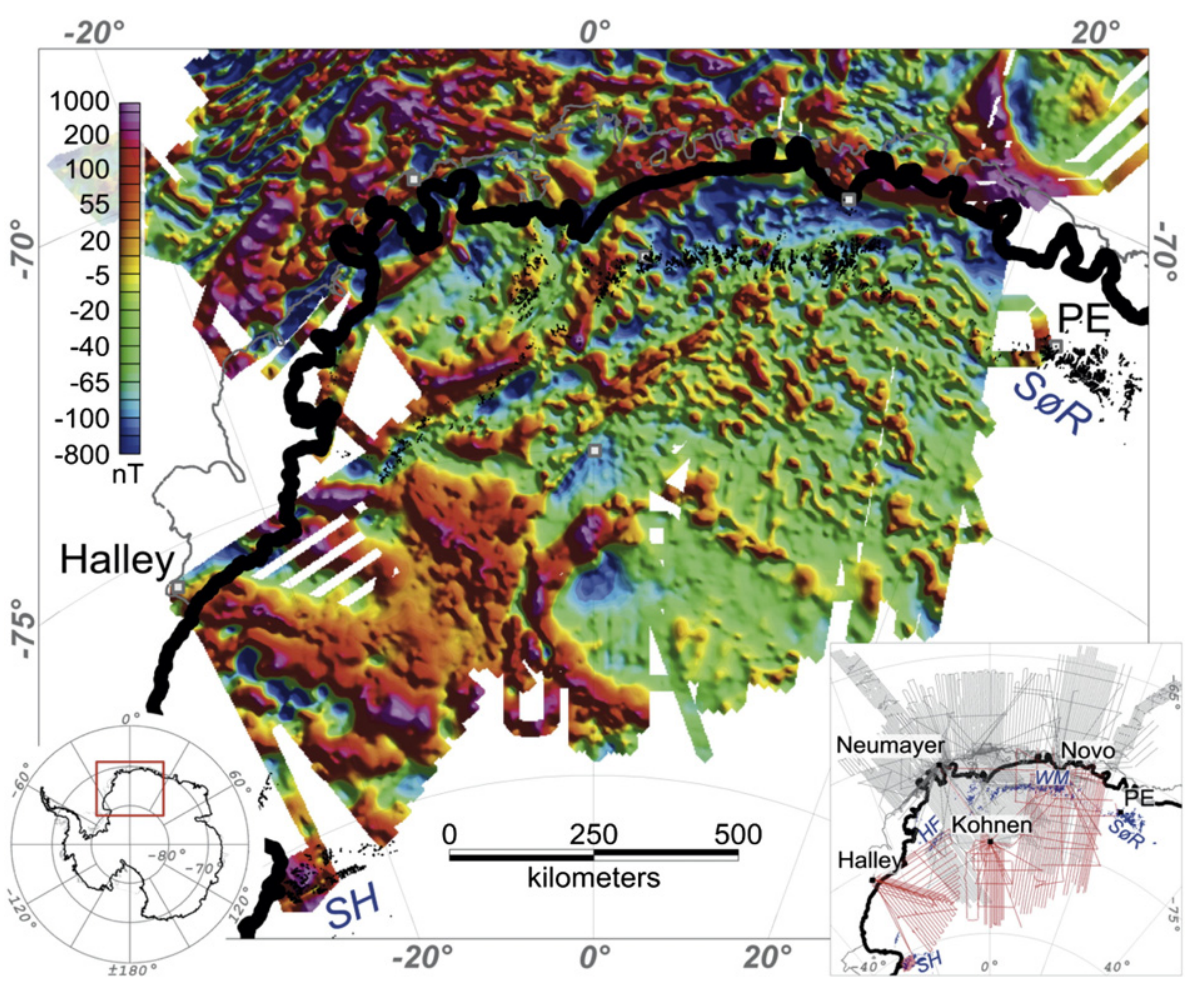

Fig. 2. Aeromagnetic anomaly map of Dronning Maud Land and Coats Land. Inlay shows AWI-survey lines (1994-2012). Abbreviations: HF - Heimefrontfjella, PE - Princess Elisabeth, SH - Shackleton Range, SøR - Sør Rondane, WM - Wohlthat Massiv.

in eastern DML, yet not the Sør Rondane region itself. The geological structure of Sør Rondane is quite similar to that of central DML, with a Proterozoic basement, medium- to high-grade metamorphic reworking during Pan-African times and intrusions of plutonic rocks and minor mafic dykes (Shiraishi et al., 1994). Several Pan African aged events have been identified, an early granulite facies metamorphism in the northeastern terrane (600-650 Ma) and an amphibolite facies metamorphism ( $570 \mathrm{Ma})$ in the southwestern terrane, which was followed by granotoid intrusions and contact metamorphism (560-500 Ma), (Shiraishi et al., 2008). Important to note is the existence of an ENE-WSW trending main shear zone in the southwestern terrane. The terrene south of this main shear zone is dominated by partly undeformed granodiorites (Ruppel, 2012). Hence, the grade of metamorphism is decreasing from $\mathrm{N}$ to $\mathrm{S}$.

Dark graphite- and pyrite-bearing schists have recently been discovered at moraines near the Steingarden nunataks $\left(72.3^{\circ} \mathrm{S} / 16.1^{\circ} \mathrm{E}\right)$. Similar metamorphosed black-shale-type sediments have not been reported from anywhere else in central DML, but higher grade metamorphosed equivalents have been found in SøR (Schlüter et al., 2011).

The Shackleton Range is situated in the westernmost part of the investigated area at $80^{\circ}-81^{\circ} \mathrm{S}$ and $19-31^{\circ} \mathrm{W}$ (Fig. 1, SH). It is a key area for studying the geological architecture of Antarctica and reconstructing the Gondwana assembly. A prominent E-W striking and southward directed thrust fault caused by nappe tectonics (Kleinschmidt et al., 2001) separates the southern terrane, regarded to be part of the East Antarctic craton, and the northern terrane which underwent Pan-African highgrade deformation between 530 and $500 \mathrm{Ma}$, while in both terranes Paleoproterozoic ortho- and paragneises show a high-grade metamorphism at $\sim 1.7$ Ga (e.g. Clarkson et al., 1995; Tessensohn et al., 1999; Zeh et al., 2004 and references herein). The latter distinguishes the Shackleton Range basement from the Grenvillian $(\sim 1.1 \mathrm{Ga}$ ) basement of the Maud belt in western and central DML, whereas orientation and collisionalrelated Pan African orogenic processes can be correlated to similar processes in DML, rather than to the coeval, yet orthogonal oriented subduction-related Ross-orogeny processes of the Transantarctic Mountains (Kleinschmidt et al., 2001).

The exposure of an ophiolitic complex at Herbert Mountains in the northern terrane is of high relevance for Gondwana reconstructions. It is a relict of oceanic crust younger than $1 \mathrm{Ga}$ and older than $500 \mathrm{Ma}$, presumably a part of the Mozambique Ocean (Talarico et al., 1999). Thus, the Shackleton Range is part of the E-W Gondwana collision. It has been proposed in several studies that the Shackleton Range suture zone continues underneath the ice-covered southern part of DML to Lützow Holm Bay region in eastern DML (e.g. Grunow et al., 1996) or further to the Prydz Bay region (Boger and Miller, 2004; Kleinschmidt and Boger, 2009), however, these models are challenged by our data.

North of the Shackleton Range, only the few nunataks of Touchdown Hills (Bertrab, Littlewood, and Moltke) at Vahsel Bay $\left(77.9^{\circ} \mathrm{S} / 34.3-\right.$ $35.5^{\circ} \mathrm{W}$ ) provide an insight into the subglacial geological basement of Coats Land. The exposed rhyolites and granophyres at Bertrab and Littlewood nunataks, emplaced $\sim 1.1 \mathrm{Ga}$, show no significant PanAfrican metamorphic overprint (Gose et al., 1997). The ages of meta-sediments at Moltke nunatak are unknown, but they are interpreted to be older than $1.1 \mathrm{Ga}$, thus, this area may represent an independent cratonic province named Coats Land block or BLM after the nunataks Bertrab, Littlewood, and Moltke (Kleinschmidt, 2002) separated from the Grunehogna province by the Maud belt (Fig. 1). The emplacement of the igneous rocks is coeval with the Umkondo LIP, but paleomagnetic data showed a separation of $\sim 30^{\circ}$ of latitude at 1.1 Ga (Gose et al., 1997). Pb isotopic data of the igneous rocks of Coats Land showed both a strong correlation with Keweenawan-LIP of Laurentia and no overlap with Umkondo LIP - implying that the BLM province is possibly a fragment of Laurentia (Loewy et al., 2011) and an important tracer for Rodinia reconstruction models. The western extent of the BLM province was identified by Russian aeromagnetic and gravity data (Studinger and Miller, 1999; Golynsky and Aleshkova, 2000), while the eastern extent remained undefined until this study. 
Fig. 1 shows a simplified sketch of the tectonic features of DML and Coats Land, as briefly reviewed herein, and their linkage to adjacent regions. For a broader picture of the geology of East Antarctica, we refer to the overview paper of Meert (2003), Satish-Kumar et al. (2008), Talarico and Kleinschmidt (2009), and Boger (2011).

\section{Data acquisition and processing}

Over $260000 \mathrm{~km}$ of magnetic survey lines have been acquired in DML by AWI from 1994 to 2012. An area of about 2.3 million $\mathrm{km}^{2}$ was covered with a general line spacing of $10 \mathrm{~km}$ (Fig. 1-inlay). Scintrex Cs-2 Caesium magnetometers were installed in the wing tips of "Polar 2" and "Polar 4" (both Dornier DO-228), in nose and tail booms of "Polar 5" (Basler BT-67), or towed 35 m below the helicopter on offshore campaigns (operated from RV-Polarstern). Scintrex Cs-3 Caesium magnetometers have been used in nose and tail booms of "Polar 6" (Basler BT-67) since 2011. On all fixed-wing aircrafts, a fluxgate magnetometer was installed and used for magnetic compensation.

Data processing was carried out using Fugro-LCT and Geosoft Oasis Montaj software. The processing flow included de-spiking, core-field and diurnal variation correction, upward continuation to $4600 \mathrm{~m}$ for onshore and $350 \mathrm{~m}$ for offshore data, as well as leveling. Static shift corrections were applied between the different survey areas - notably, the survey over Coats Land from 1994/95 was shifted by +109 nT, reducing the cross-point errors from $54.1 \pm 64.1 \mathrm{nT}$ to $21.7 \pm 25.2 \mathrm{nT}$, followed by low pass filtered tensional spline correction, reducing the cross-point error to $4.0 \pm 5.3 \mathrm{nT}$.

The offshore data have been previously used to refine kinematic models for the early Gondwana break-up (Jokat et al., 2003; König and Jokat, 2006; Leinweber and Jokat, 2012) and are not shown here. The onshore data cover a large area of 1.5 million $\mathrm{km}^{2}$ - nearly half the size of India.

The magnetic anomaly maps in Figs. 3 and 4 are superimposed on data from the Antarctic Digital Magnetic Anomaly Project (ADMAP, Golynsky et al., 2007). Data sets have been reduced to the pole with a mean inclination (I) and declination (D) for each region $\left(I_{\text {fig } 3}=-63^{\circ}, \quad D_{\text {fig3 }}=-31^{\circ}, \quad I_{\text {fig } 4 a}=-64^{\circ}, \quad D_{\text {fig } 4 \mathrm{a}}=-6^{\circ}\right.$, $\mathrm{I}_{\text {fig } 4 \mathrm{~b}}=-67^{\circ}, \mathrm{D}_{\text {fig } 4 \mathrm{~b}}=1^{\circ}$, and $\mathrm{I}_{\text {fig5 }}=-64^{\circ}, \mathrm{D}_{\text {fig } 5}=-19^{\circ}$ ), as we assume that induced magnetization is dominant in the onshore region. Derivative maps (analytical signal, positive tilt derivative, and enhanced horizontal derivative) have been calculated for the area of the Kohnen lineament (Fig. 5) in order to enhance the source boundaries. Calculation of the enhanced horizontal derivative map was based on the method of Fedi and Florio (2001), with first order vertical derivative of the reduced to the pole field as start signal.

\section{Results}

\subsection{Magnetic anomaly pattern of southeastern Dronning Maud Land}

A very large area $(600 \mathrm{~km} \times 900 \mathrm{~km})$ of a rather weak magnetic anomaly field (Fig. 3, A) dominates the magnetic pattern of southeastern DML. This area contains narrow $(10-20 \mathrm{~km})$ and elongated (100-200 km) positive, small amplitudes anomalies (50-100 nT) (Fig. 3, white lines). These anomalies are parallel oriented and strike NW-SE. They are truncated by the Forster Magnetic Anomaly (Fig. 3, FMA) in the NW and confined by the Wohlthat Massif (Fig. 3, $\mathrm{WM}$ ) in the north, but they can be traced farther east (Fig. 3, blue dashed lines) where ADMAP data are available. However, the actual extent of this anomaly pattern remains unknown due to the sparse line spacing and data gaps of existing ADMAP-data in the east. The

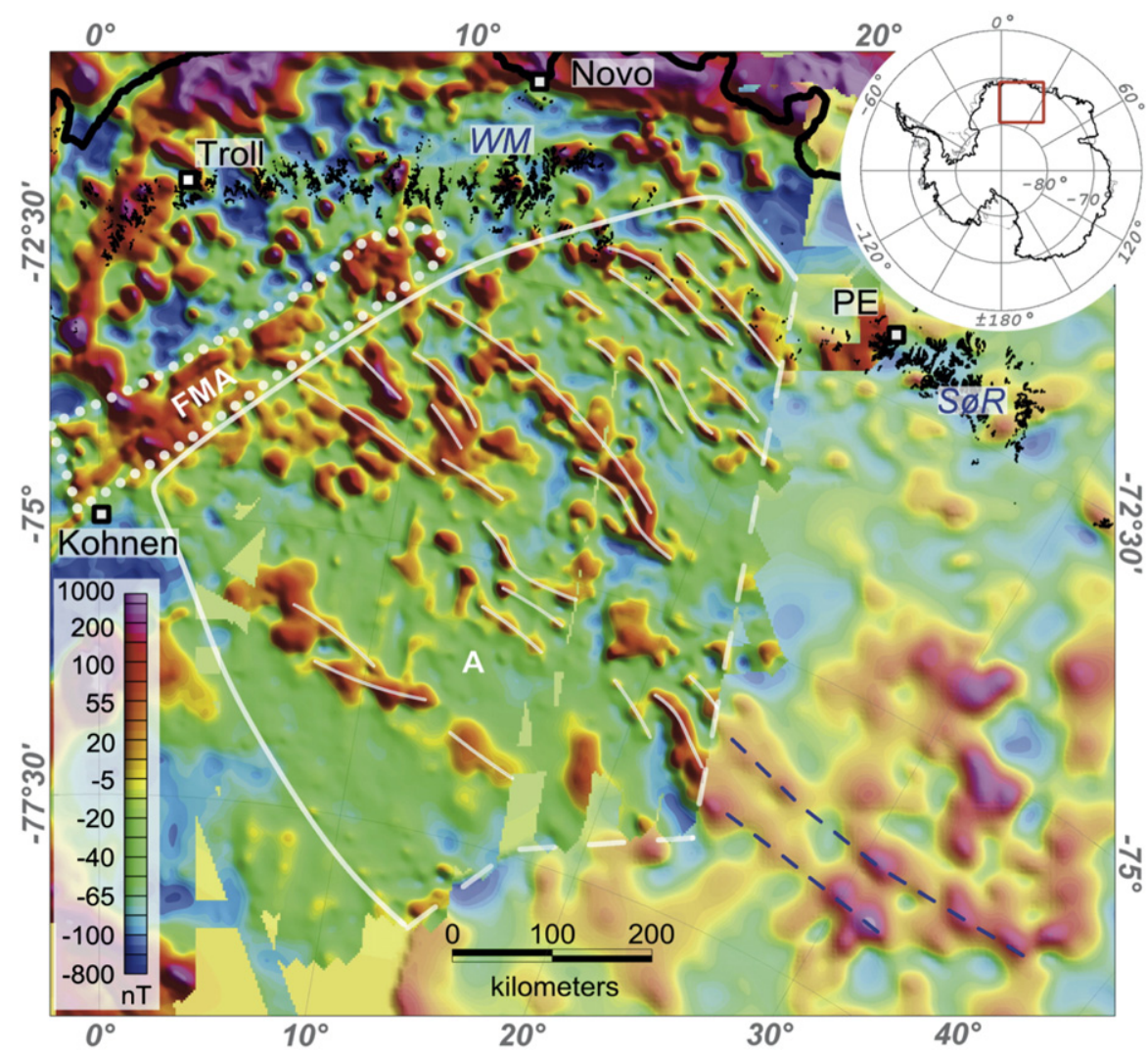

Fig. 3. Aeromagnetic anomaly map of southeastern Dronning Maud Land. Data are superimposed on ADMAP data (Golynsky et al., 2007) in pale colors (no grid-knitting applied), both maps are reduced to the pole (inclination $=-63^{\circ}$, declination $=-31^{\circ}$ ). Anomaly area A characterizes the southeastern Dronning Maud Land province by a weak magnetic amplitude level with parallel elongated positive anomalies of 50-100 nT (white lines). Abbreviations: FMA - Forster Magnetic Anomaly, PE - Princess Elisabeth, SøR - Sør Rondane, WM - Wohlthat Massiv. 


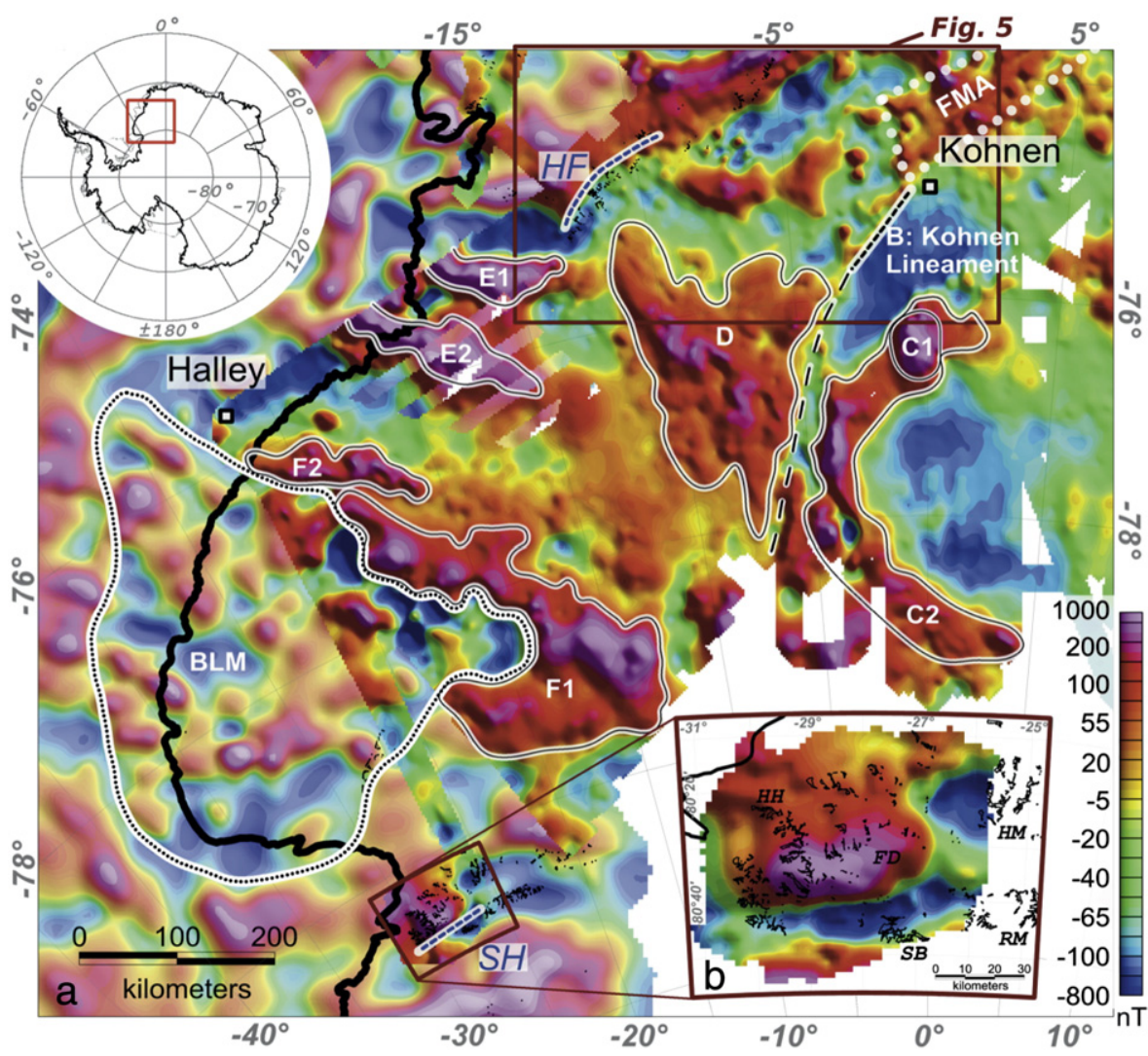

Fig. 4. (a) Aeromagnetic anomaly map of southwestern Dronning Maud Land and Coats Land. Data are superimposed on ADMAP data (Golynsky et al., 2007) in pale colors (no grid-knitting applied), both maps are reduced to the pole (inclination $=-64^{\circ}$, declination $=-6^{\circ}$ ). In this study, anomaly B is named Kohnen lineament. $\mathrm{C}-\mathrm{F}$ are other discussed magnetic anomalies. Abbreviations: BLM - Bertrab-Littlewood-Moltke province (Coats Land block), FMA - Forster Magnetic Anomaly, HF - Heimefrontfjella, SH - Shackleton Range. (b) Aeromagnetic anomaly map over western Shackleton Range. Same color scale is used for both figures. Survey lines are $6 \mathrm{~km}$ separated. Mean flight level was $2400 \mathrm{~m}$ (a.s.l.). Data are not upward continued, but reduced to the pole (inclination $=-67^{\circ}$, declination $=1^{\circ}$ ). Abbreviations: FD - Fuchs Dome, HH - Haskard Highlands, HM - Herbert Mountains, RM - Read Mountains, SB - Stephenson Bastion.

magnetic anomaly field in area $\mathrm{A}$ is, in general, so smooth that a correction of diurnal variation as well as leveling techniques can introduce artificial anomalies along survey lines, but fortunately the trend direction significantly deviates by $\sim 55^{\circ}$ from the main flight direction, ensuring the reliability of the presence of the elongated anomalies.

The Forster Magnetic Anomaly south of the central DML mountain range is one of the most interesting findings of Riedel et al. (2013). This nearly $400 \mathrm{~km}$ long and $65 \mathrm{~km}$ wide feature consists of a system of segmented linear SW-NE trending anomalies with moderate positive values up to $200 \mathrm{nT}$, truncating the elongated anomalies of area A by an angle of $\sim 80^{\circ}$. Notably, the data SE of the Forster Magnetic Anomaly presented here differ from Riedel et al. (2013), since two additional surveys have densified the line spacing to $10 \mathrm{~km}$ in the meantime, and significantly increased the number of tie lines.

\subsection{Magnetic anomaly pattern of southwestern Dronning Maud Land} and Coats Land

Our data revealed a weak but linear local maximum SW of Kohnen Station (Fig. 4, B), striking NE-SW. The anomaly, here named Kohnen lineament, is about $100 \mathrm{~km}$ long and less than $10 \mathrm{~km}$ wide and is characterized by a sharp gradient toward negative values in the SE. A $30 \mathrm{~km}$ wide and $240 \mathrm{~km}$ long trough characterized by small magnetic anomalies (Fig. 4, dashed white line) follows in SW-projection of the Kohnen lineament. This trough separates the magnetic highs $\mathrm{C} 1 / \mathrm{C} 2$ and $\mathrm{D}$.

Fig. 5 shows the derivative maps for a subsection including the Kohnen lineament and the Heimefrontfjella, together with the actual survey lines. The analytical signal and the positive tilt derivative enhance the linearity of the Kohnen lineament and show its similarity to magnetic anomaly of the Heimefront shear zone. We derived the location of the Kohnen lineament between $74.995^{\circ} \mathrm{S} / 0.684^{\circ} \mathrm{W}$ and $75.667^{\circ} / 2.742^{\circ} \mathrm{W}$ from the enhanced horizontal derivate map. The derivative maps also enhance three small circular anomalies close to the western flank of the Kohnen lineament, with a diameter of 8-10 km and peak values of $110 \mathrm{nT}, 120 \mathrm{nT}$, and $180 \mathrm{nT}$.

A strong positive (>400 nT) anomaly with a radius of $100 \mathrm{~km}$ is located directly $200 \mathrm{~km}$ south of the Kohnen station (Fig. 4, C1). It is part of an arch-shaped, high amplitude feature (100-400 nT) (Fig. 4, C2), which is $\sim 500 \mathrm{~km}$ long and $\sim 70 \mathrm{~km}$ wide, most likely continuing beyond the southern extent of our survey area. Broad negative anomalies (up to $-150 \mathrm{nT}$ ) have been found north and south of the positive anomaly $\mathrm{C} 1$.

The nearly triangle shaped area (Fig. 4, D) of moderate to high anomalies (50-250 nT) has an areal extent of about $80000 \mathrm{~km}^{2}$. In the NW, it reaches almost to the Heimefront shear zone, and is bounded by the extension of the Kohnen lineament in the $\mathrm{E}$. The joint leveling with data from 1994/95 and 2011 significantly improved the regional magnetic anomaly pattern in this region. In contrast to Riedel et al. (2013), this more complete data set shows a more diffuse anomaly pattern and no dominating NW-SE strike direction for area D.

Farther west two high amplitude anomalies (Fig. 4, E1 \& E2) are located SW of HF. Both anomalies are $\sim 40 \mathrm{~km}$ wide and have amplitudes of up to $500 \mathrm{nT}$.

After superimposing our data set on top of ADMAP data, a unique magnetic anomaly pattern became recognizable in Coats Land (Fig. 4, BLM). Golynsky and Aleshkova (2000) described the BLM pattern as intricate or broken and composed of irregular high anomalies $( \pm 300 \mathrm{nT})$ of short wavelength $(20-50 \mathrm{~km})$. Our data confirm this unique pattern and allow us to constrain its eastern extent. The 

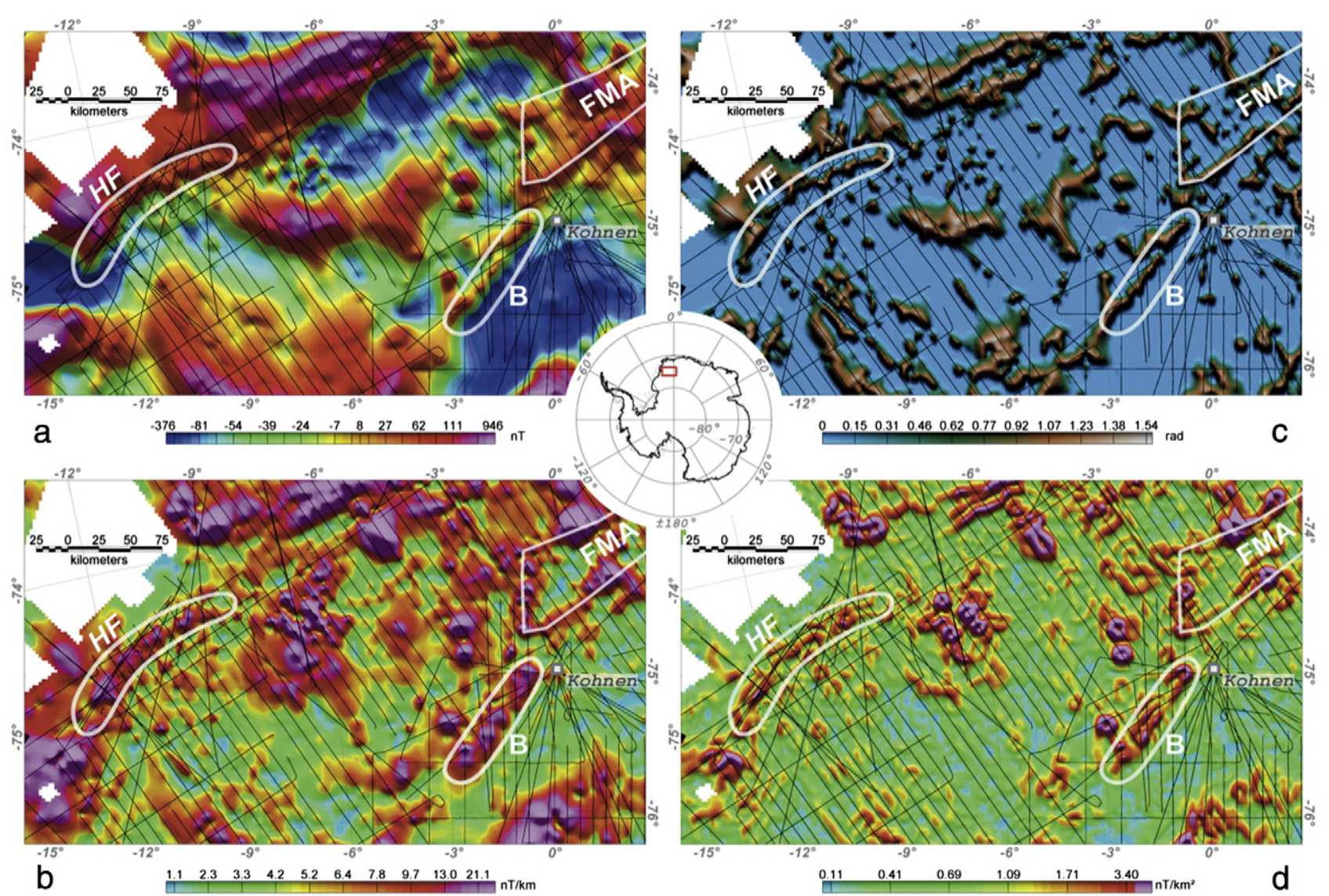

Fig. 5. Derivative aeromagnetic anomaly maps of Kohnen lineament and Heimefront shear zone: (a) reduced to the pole (inclination $=-64^{\circ}$, declination $=-19^{\circ}$ ), $(\mathrm{b})$ analytical signal, (c) positive tilt derivative, and (d) enhanced horizontal derivative. Survey lines (black) are not along strike direction of the Kohnen lineament. Abbreviations: B - Kohnen lineament, FMA - Forster Magnetic Anomaly, HF - Heimefrontfjella.

BLM area is surrounded by anomalies of moderate to small amplitudes $(-100$ to $150 \mathrm{nT})$ and two large anomalies of high amplitudes (400 nT) of wavelengths above $100 \mathrm{~km}$ (Fig. 4, F1 \& F2). Notably, the southern extent is not well constrained by our data and is therefore based on the interpretation of Golynsky and Aleshkova (2000).

The western Shakleton Range (Fig. 4, SH) was investigated with a local pattern of $6 \mathrm{~km}$ line spacing across the exposed mountain range, using a barometric flight altitude of only $2400 \mathrm{~m}$. The content of information was clearly reduced by the upward continuation to $4600 \mathrm{~m}$. Therefore, a separated anomaly map of magnetic data that was not upward continued and not statically shifted over western Shackleton Range is shown in Fig. 4b. The data show a magnetic high (up to 570 nT) over Fuchs Dome (Fig 4b, FD) and Haskard Highlands (Fig. 4b, $\mathrm{HH}$ ), both part of the northern terrane, and a narrow (8 $\mathrm{km}$ wide) linear E-W oriented magnetic low (up to $-220 \mathrm{nT}$ ) over the Stephenson Bastion (Fig. 4b, SB), also extending easterly towards the Read Mountains (Fig. 4b, RM), both part of the southern terrane. The ADMAP data show negative magnetic anomaly values for the entire Read Mountains. Negative magnetic anomaly values (up to $-190 \mathrm{nT}$ ) are measured as well near the Herbert Mountains (Fig. 4b HM). Another magnetic high is indicated at the southern edge of our data and south of the exposed mountains, which is in accordance with the ADMAP data (Fig. 4).

\section{Interpretations and discussion}

\subsection{Southeastern Dronning Maud Land province}

The discovery of the elongated, small amplitude magnetic anomalies between Sør Rondane and Kohnen Station (Fig. 6, A) sheds new light on pre-break-up tectonic evolution of Gondwana in East Antarctica. We assume that these elongated anomalies are real and represent a predominant structural strike direction of a major geological unit, here named southeastern DML province. This pattern is observed currently in an area of at least $270000 \mathrm{~km}^{2}$. The Steingarden nunataks $\left(72.3^{\circ} \mathrm{S} / 16.1^{\circ} \mathrm{E}\right)$ might provide a clue for interpreting the magnetic anomalies, since the Nunataks are located at the northern edge of the southeastern DML province between Wohlthat Massif and Sør Rondane, and were visited for the first time by scientists searching for meteorites in 2007/2008 (Schlüter et al., 2011) and by geologist in 2011/2012 (Jacobs et al., 2012). Unfortunately, no information on the magnetic susceptibilities as well as age constraints are available for the dark graphite- and pyrite-bearing schists found on moraines south of the Nunataks, but they indicate that the geological evolution of the southeastern DML province differs from that of the central DML mountain range. The weak amplitude level of this region differs clearly from the high amplitude anomalies in southwestern DML. Hence, we interpret the southeastern DML province to be a distinct geological terrane, separated from the southwestern DML (Fig. 6). In the same manner, this region differs from the magnetic Ruker province west of the Prydz Bay region (Fig. 6, gray dotted line, around Mellor Anomaly), which is dominated by negative magnetic amplitudes of $-300 \mathrm{nT}$ (Golynsky, 2007) and lacks any indication for elongated positive anomalies.

We speculate that the southeastern DML province underwent a metamorphic deformation under compressional forces perpendicular to the strike direction of the anomaly pattern. Considering the possible continuation of this magnetic pattern in the east (Figs. 3 and 6, blue dashed lines), the anomaly pattern might represent the NW part of an orogenic belt of unknown age, but some indications about the timing can be argued as follows. 


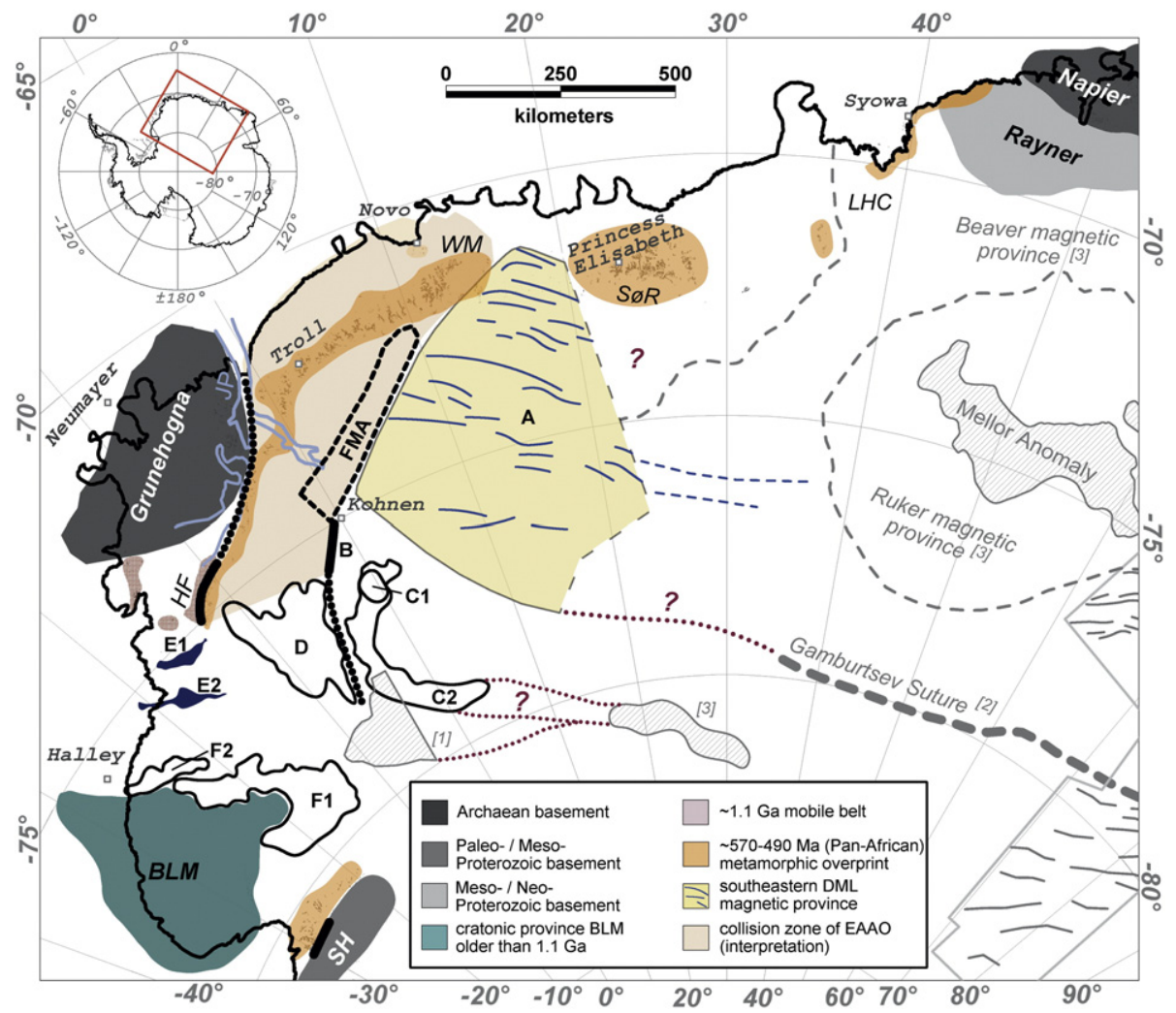

Fig. 6. Interpretive sketch of magnetic anomalies (A-F, BLM), geological information, and presumed continuations of magnetic anomalies (dark-red dotted lines). Magnetic information from other studies are included: [1] Shepherd et al. (2006), [2] Ferraccioli et al. (2011), and [3] Golynsky (2007) - magnetic high (gray dashed area), elongated anomalies (gray lines), and province boundaries (gray dashed lines). Abbreviations: BLM - Bertrab-Littlewood-Moltke province (Coats Land block), FMA - Forster Magnetic Anomaly, HF - Heimefrontfjella, LHC - Lützow Holm Complex, SH - Shackleton Range, SøR - Sør Rondane, WM - Wohlthat Massiv.

First, the truncation of the elongated anomalies in the NW by the Forster Magnetic Anomaly (Figs. 3 and 6) strongly supports the hypothesis of Riedel et al. (2013) that the Forster Magnetic Anomaly represents a major fault or even suture zone, which is, in absence of direct geological measurement, interpreted as a Pan African (650-490 Ma) structure (Riedel et al., 2013). We conclude that the formation of the elongated magnetic anomalies predates the formation of the Forster Magnetic Anomaly.

Second, Sør Rondane Mountains are located at the NW edge of our data. At the moment, it is unclear if it is part of the southwestern DML province or not. The mountain range show Pan-African deformation with a decreasing grade of metamorphism from $\mathrm{N}$ to $\mathrm{S}$, and the Pan-African aged main shear zone could mark the boundary of the southeastern DML province, which would indicate that the elongated anomalies represent an older structure.

Third, based on aeromagnetic data, Golynsky (2007) interpreted the region east of the southwestern DML province as a continuous crustal province (Rayner-Beaver province) around the Archean Ruker province, extending to the Prydz Bay region as well as to the northern Gamburtsev Mountains. How far the elongated anomalies extend into this region is unclear due to the sparser line spacing there, but high-resolution aeromagnetic data show anomalies with a similar wavelength and orientation at Prydz Bay (Golynsky et al., 2006) and southern Prince Charles Mountains (Damaske and McLean, 2005). McLean et al. (2009) showed that these anomalies in the western Prydz Bay region correlates with orthogneisses of the Porthos series and intrusive charnockites, which both have much higher magnetic susceptibilities $\left(1-100 * 10^{-3} \mathrm{SI}\right.$ units) compared to the surrounding paragneisses of the Athos series $\left(\sim 0.5 * 10^{-3}\right.$ SI units). The emplacement age of the Porthos orthogneisses is interpreted as late Mesoproterozoic-early Neoproterozoic ( 1020 Ma) by ${ }^{207} \mathrm{~Pb} /{ }^{206} \mathrm{~Pb}$ ratios (Boger et al., 2000). If the southern DML Province and Prydz Bay region, separated by $\sim 1500 \mathrm{~km}$, form actually one geological unit, both time constrain and rock information can be deduced from the findings in the Prydz Bay region. Moreover, the Gamburtsev suture (Ferraccioli et al., 2011) lines up with the western extent of the southeastern DML province (Fig. 6), and it could be speculated that the Gamburtsev suture follows this line, but that is not supported by the existing, but sparse ADMAP data. It is necessary to close the highresolution data gap to provide better constraints on its origin. Notably, similar magnetic trends (Fig. 6, gray lines) exist in southern Gamburtsev Mountains (Ferraccioli et al., 2011).

\subsection{Kohnen lineament}

The Kohnen lineament (Figs. 4, 5, and 6, B) SW of the Kohnen Station is the most important new finding in the southwestern part of our study area. Similarities to the magnetic anomaly pattern of the Heimfront shear zone are shown in Fig. 5. Both anomalies striking NW-SE and are separated by $\sim 300 \mathrm{~km}$. The Heimefront shear zone is regarded to represent the western front of the East African-Antarctic orogen (Golynsky and Jacobs, 2001). Subsequently, we interpret the Kohnen lineament as a major shear zone, possibly representing the eastern front of this orogen in this region. The Forster Magnetic Anomaly adjoins the Kohnen lineament in the NE accompanied by a change in orientation by $\sim 20^{\circ}$. We follow the presumption of Riedel et al. (2013) that the Forster Magnetic Anomaly represents a collision zone, namely of the southeastern DML province with W-Gondwana, and speculate that the formation of the Kohnen lineament was caused mainly by shearing, which is in alignment with the escape tectonic model of Jacobs and Thomas (2004).

The magnetic trough SW of the Kohnen lineament (Fig. 4, black dotted line) could be a continuation of this eastern front, though its magnetic signature is different. It separates the magnetic highs $\mathrm{C} 1 / \mathrm{C} 2$ in the east from the nearly triangularly shaped anomaly D of moderate 
positive values in the west (Fig. 4). The interpretation of anomaly D is of yet unclear. It could very well represent a collision fragment of the East African-Antarctic orogen as well as an independent geological terrane. Our new data set shows that it is not a continuation of the Forster Magnetic Anomaly, which differs from the presumption of Riedel et al. (2013) based on a less complete data set.

\subsection{Possible continuation of the Beattie magnetic anomaly}

In the westernmost part of our research area, two $\sim 40 \mathrm{~km}$ wide magnetic highs (Figs. 4 and 7, E1 and E2) allow the interpretation that both features are the eastward continuation of the Beattie Magnetic Anomaly in southern Africa into East Antarctica (Fig. 7, BMA), based on the latest tight fit in the Gondwana reconstruction of this region by Leinweber and Jokat (2012). This interpretation differs from Corner (1989) and the concretized location of Riedel et al. (2013), who suggested a continuation of the Beattie Magnetic Anomaly into DML farther north. It is feasible that both interpretations are valid and that the anomaly splits into three branches, similar to the bifurcation at its westerly extent in southern Africa. The Beattie Magnetic Anomaly has no gravity expression and its interpretation is speculative. Corner (1989) suggested magnetite enrichment in granitic basement as a source, while Lindeque et al. (2011) interpreted the origin as a partly mineralized massive sulfide-magnetite ore deposit at a depth of $\sim 7$ to $15 \mathrm{~km}$. The new magnetic data provide no additional information on the composition of the magnetic source bodies of the Beattie Magnetic Anomaly, as there are no outcrops located at anomalies E1 and E2, but the interpretation might help to reconstruct a tight fit for microplates (e.g. Falkland Islands) between East Antarctica and Africa.

\subsection{BLM province (Coats Land block)}

Another area for which our magnetic data set provides new information is the BLM province in Coats Land (Fig. 6, BLM). The outline of this province is well defined by its irregular positive and negative short wavelength (40-60 km) anomalies (Fig. 4, BLM)). Golynsky and Aleshkova (2000) discussed a possible relation of the magnetic anomalies to the few outcrops at Touch Down Hills and Theron Mountains, but due to the line spacing, a direct correlation was not possible. What is new here is the mapping of the eastern extent and that its unique anomaly pattern is not found elsewhere in Coats Land, DML, and southern Africa, supporting the hypothesis that the BLM province was neither a part of Kalahari nor of the southern DML before amalgamation of Rodinia. Comparisons with magnetic anomaly maps worldwide (Maus et al., 2007) reveal similarities with anomaly patterns in Baltica and Laurentia. This is in accordance with the findings of Loewy et al. (2011), who showed strong $\mathrm{Pb}$ isotopic correlation of rhyolites and granophyres of the BLM province and Keweenawan igneous rocks of Laurentia, as well as with the paleomagnetic indication of a separation of Kalahari and the BLM province by $30^{\circ}$ in latitude (Gose et al., 1997). Moreover, Kleinschmidt (2002) discussed that the rocks of the Touch Down Hills nunataks differ petrologically, lithologically and structurally from those found in western Dronning Maud Land, and that they match neither the low- to highgrade metamorphic basement rocks nor the Pan-African reworking of the of the northern terrane of the Shackleton Range.

\subsection{Southwestern DML and Shackleton Range}

Rather speculative and not geologically constrained are the interpretations of magnetic highs $\mathrm{C} 1 / 2, \mathrm{D}$, and F1/F2. Similarities to the magnetic anomaly pattern of the NW Shackleton Range terrane can be drawn by appearance and amplitude level. Although this very weak similarity does not allow any conclusions, it shows that an interpretation of the Precambrian basement is potentially feasible. This interpretation is also provided by Shepherd et al. (2006), for a magnetic high that partly overlaps with anomaly C2 (Fig. 6).

Another, yet very unlikely, hypothesis would be the presumption of massive Jurassic magmatic rocks as a source. Dykes and sills of Jurassic dolorities are found in our study area along the Jutul-Penck graben, at Theron Mountains and at the northern Shackleton Range terrane, but they correlated with much higher frequency magnetic anomalies (Golynsky and Aleshkova, 2000; Ferraccioli et al., 2005b; Shepherd et al., 2006). The circular shape of anomaly C1 suggests an intrusive source body. The similar, yet in extension much smaller, magnetic anomalies of Straumsvola and Tvora at the eastern flank of the Jutul-Penck graben have been correlated with mid-Jurassic alkaline intrusions (Ferraccioli et al., 2005b).

However, we prefer the interpretation of exposed Pre-Cambrian basement for the largely extended magnetic highs. It is not unlikely that anomalies F1/F2 represent the collision zone between the BLM province

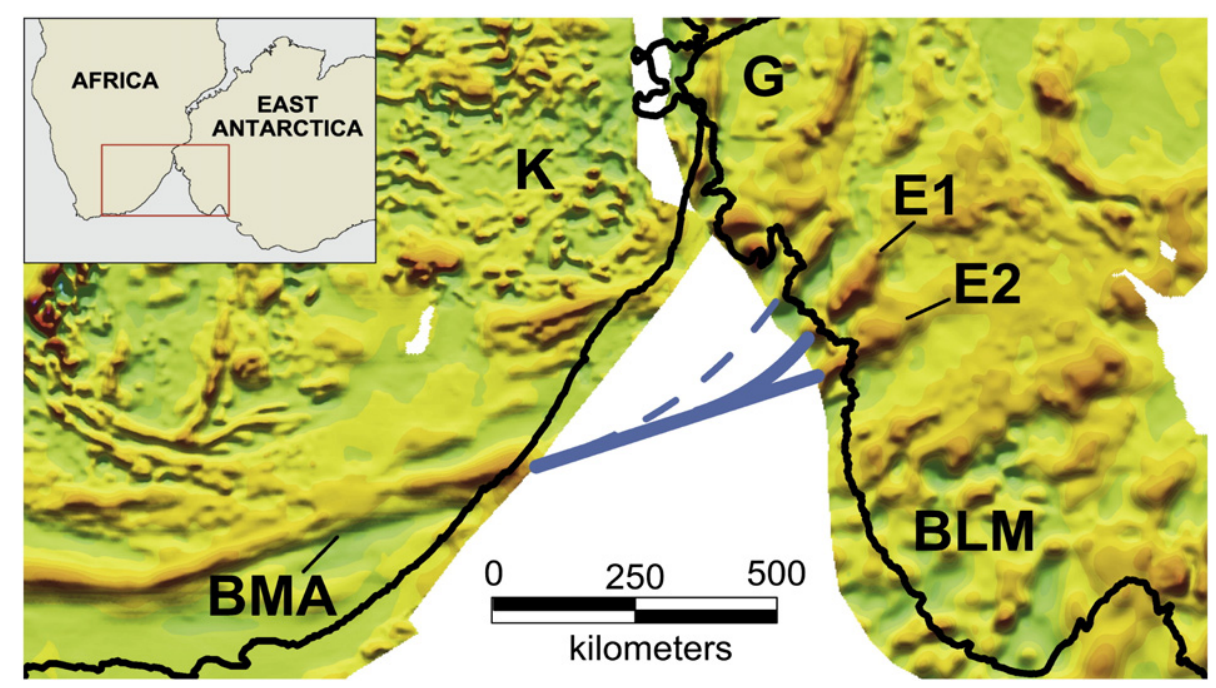

Fig. 7. Supposed continuation of Beattie Magnetic Anomaly. Magnetic anomaly map of Antarctica is a compilation of AWI-data (this paper) and ADMAP data (Golynsky et al., 2007), for Africa data from Maus et al. (2007) are used. Reconstruction of Africa and Antarctica carried out after Leinweber and Jokat (2012) with tight fit 189 Ma. A linear color scale is used, blue and green representing negative values, orange and red positive values. Abbreviations: BLM - Betrab-Littlewood-Molke province (Coats Land block), BMA - Beattie Magnetic Anomaly, E1/E1 magnetic highs, G - Grunehogna Craton, K - Kaapvaal Craton. Continuous blue lines proposed continuation in this study, dashed blue line indicated by Riedel et al. (2013). 
and the Namaqua-Natal-Maud belt. From Shepherd et al. (2006) we know that anomalies F1 and C2 are disconnected (Fig. 6), and we assume that $\mathrm{C} 2$ continues $\mathrm{SE}$, where it might connect to a magnetic high at $80-82^{\circ} \mathrm{S} / 30-55^{\circ} \mathrm{E}$, forming a continuous S-shaped $1000 \mathrm{~km}$ long anomaly (Fig. 6). Notably, only data of the end of one survey line contributed to the circular magnetic low within C2. Therefore, we do not interpret this small-scale anomaly, as it cannot be determined if the data had been corrupted during measuring or pre-processing.

Regardless of the interpretation of the magnetic highs in southwestern DML, we note that the overall pattern of this area, with its high and diversified amplitudes, differs clearly from the coherent weak amplitude pattern in the southeastern DML province, supporting our assumption of a separated tectonic terrane SE of the Forster Magnetic Anomaly and, at the same time, opposing the hypothesis of a structural link between Shackleton Range and Lützow Holm Bay region in eastern DML.

\section{Conclusion}

We have presented a compilation of new reconnaissance aeromagnetic data in the southern part of Dronning Maud Land and eastern Coats Land, and mapped provinces and boundaries for the first time in this mostly ice-covered part of East-Antarctica, and discussed some indications of their geological meaning and importance for studying the tectonic evolution of East-Antarctica, which appears to be a mosaic of several distinct crustal provinces. The main conclusions are:

- A hitherto unrecognized southeastern Dronning Maud Land province is characterized by parallel and NW-SE trending elongated positive (50-100 nT) magnetic anomalies and a weak background amplitude level. An eastward continuation into the Beaver-Rayner province is indicated, and a hypothesis can vaguely be formulated that the elongated anomalies may be caused by charnockitic felsic gneiss of Meso- to Neoproterozoic age as part of a continuous mobile belt extending out into the Prydz Bay region, but it needs to be pointed out that the reliability of this hypothesis is very weak, as it is based only on the similarities in grain of magnetic patterns.

- The Kohnen magnetic lineament may reflect a major shear zone in the interior of East Antarctica akin to the Pan-African aged Heimefront shear zone. It adjoins the Forster Magnetic Anomaly, which we interpret to represent the collision zone of the southeastern Dronning Maud Land province with West-Gondwana.

- The magnetic anomaly maps provide no evidence of a previously hypothesized continuous Pan-African orogenic belt or suture zone connecting the Shackleton Range and the Lützow Holm Bay region in eastern Dronning Maud Land.

- The easterly extent of the possible cratonic BLM province (Coats Land block) is mapped and it is pointed out that its magnetic amplitude pattern is unique for Dronning Maud Land and southern Africa, yet showing similarities to those of Laurentia and Baltica.

- Two anomalies in western Dronning Maud Land have been identified as possible continuations of the Beattie Magnetic Anomaly, in addition to a previously assumed continuation in this region.

\section{Acknowledgments}

We thank the flight and science crews of AWI-Polar aircrafts for data acquisition, the visited research station in Dronning Maud Land for logistic support, J. Jacobs and G. Kleinschmidt for inspiring discussions, the anonymous reviewer for constructive comments that significantly enhanced the manuscript, and A. Sorensen for stylistic help and improvement of the English language.

\section{References}

Boger, S.D., 2011. Antarctica - before and after Gondwana. Gondwana Research 19 (2), 335-371. http://dx.doi.org/10.1016/j.gr.2010.09.003.

Boger, S.D., Miller, J.M., 2004. Terminal suturing of Gondwana and the onset of the RossDelamerian Orogeny: the cause and effect of an Early Cambrian reconfiguration of plate motions. Earth and Planetary Science Letters 219, 35-48.

Boger, S.D., Carson, C.J., Wilson, C.J.L., Fanning, C.M., 2000. Neoproterozoic deformation in the Radok Lake region of the northern Prince Charles Mountains, East Antarctica: evidence for a single protracted orogenic event. Precambrian Research 104, 1-24.

Clarkson, P.D., Tessensohn, F., Thomson, J.W., et al., 1995. Geological map of the Shackleton Range, Antarctica. GEOMAP series, sheet 4. British Antarctic Survey, Cambridge, pp. 57-60.

Corner, B., 1989. The Beattie anomaly and its significance for crustal evolution within the Gondwana framework. Extended Abstracts. : First Technical Meeting. South African Geophysical Association, pp. 15-17.

Damaske, D., McLean, M.A., 2005. An aerogeophysical survey south of the Prince Charles Mountains, East Antarctica. Terra Antarctica 12, 87-98.

Damaske, D., Marcinkowski, V., Möller, H.D., 2005. Aeromagnetic survey in centra Dronning Maud Land, East Antarctica, during the 1995/1996 GeoMaud expedition: layout, execution, and data processing. Bundesanstalt für Geowissenschaften und Rohstoffe. Geologisches Jahrbuch 97 (B), 53-83.

Fedi, M., Florio, G., 2001. Detection of potential fields source boundaries by enhanced horizontal derivative method. Geophysical Prospecting 49, 40-58.

Ferraccioli, F., Jones, P.C., Curtis, M.L., Leat, P.T., 2005a. Subglacial imprints of early Gondwana break-up as identified from high resolution aerogeophysical data over western Dronning Maud Land, East Antarctica. Terra Nova 17 (6), 573-579.

Ferraccioli, F., Jones, P.C., Curtis, M.L., Leat, P.T., Riley, T.R., 2005b. Tectonic and magmatic patterns in the Jutulstraumen rift(?) region, East Antarctica, as imaged by high-resolution aeromagnetic data. Earth Planets and Space 57, 767-780.

Ferraccioli, F., Finn, C.A., Jordan, T.A., Bell, R.E., Anderson, L.M., Damaske, D., 2011. East Antarctic rifting triggers uplift of the Gamburtsev Mountains. Nature 479, 388-392. http://dx.doi.org/10.1038/nature10566.

Golynsky, A.V., 2007. Magnetic anomalies in East Antarctica and surrounding regions: a window on major tectonic provinces and their boundaries. In: Cooper, A.K. Raymond, C.R., et al. (Eds.), Proceedings of the 10th ISAES: USGS Open-File Report 2007-1047, Short Research Paper, 006. http://dx.doi.org/10.3133/of2007-1047.srp006.

Golynsky, A.V., Aleshkova, N.D., 2000. Regional magnetic anomalies of the Weddell Sea Region and their geological significance. Polarforschung 67, 101-117.

Golynsky, A.V., Jacobs, J., 2001. Grenville-age versus Pan-African magnetic anomaly imprints in western Dronning Maud Land, East Antarctica. Journal of Geology 109 (1), 136-142.

Golynsky, A.V., Masolov, V.N., Nogi, Y., Shibuya, K., Tarlowsky, C., Wellman, P., 1996. Magnetic anomalies of Precambrian terranes of the East Antarctic Shield coastal region $(20 \mathrm{jE}-50 \mathrm{jE})$. Proceedings of the National Institute of Polar Research Symposium on Antarctic Geosciences 9, 24-39.

Golynsky, A.V., Alyavdin, S.V., Masolov, V.N., Tscherinov, A.S., Volnukhin, V.S., 2002. The composite magnetic anomaly map of the East Antarctic. Tectonophysics 347 (1-3), 109-120.

Golynsky, A.V., Masolov, V.N., Volnukhin, V.S., Golynsky, D.A., 2006. Crustal provinces of the Prince Charles Mountains region and surrounding areas in a light of aeromagnetic data. In: Fütterer, D., et al. (Ed.), Antarctica: Contributions to Global Earth Sciences (IX ISAES Proceedings). Springer, pp. 83-94.

Golynsky, A.V., Blankenship, D., Chiappini, M., Damaske, D., Ferraccioli, F., Finn, C., Golynsky, D., Goncharov, A., Ishihara, T., Ivanov, S., Jokat, W., Kim, H.R., König, M., Masolov, V., Nogi, Y., Sand, M., Studinger, M., von Frese, R., the ADMAP Working Group, 2007. New magnetic anomaly map of East Antarctica and surrounding regions. In: Cooper, A.K., Raymond, C.R., et al. (Eds.), Proceedings of the 10th ISAES: USGS Open-File Report 2007-1047, Short Research Paper, 050. http://dx.doi.org/10.3133/of2007.srp050.

Gose, W.A., Helper, M.A., Conelly, J.N., Hutson, F.E., Dalziel, I.W.D., 1997. Paleomagnetic data and U-Pb isotopic age determinations from Coats Land, Antarctica: Implications for late Proterozoic plate reconstructions. Journal of Geophysical Research 102, 7887-7902.

Grantham, G.H., Hunter, D.R., 1991. The timing and nature of faulting and jointing adjacent to the Pencksokket, western Dronning Maud Land, Antarctica. In: Thomson, M.R.A. Crame, J.A., Thomsan, J.A. (Eds.), Geological Evolution of Antarctica, pp. 47-51.

Grosch, E.G., Bisnath, A., Frimmel, H.E., Board, W.S., 2007. Geochemestry and tectonic setting of mafic rocks in western Dronning Maud Land, East Antarctica: implications for the geodynamic evolution of the Proterozoic Maud Belt. Geological Society London 164, 465-475.

Grunow, A., Hanson, R., Wilson, T., 1996. Were aspects of Pan-African deformation linked to lapetus opening? Geology 24, 1063-1066.

Hanson, R.E., Martin, M.W., Bowring, S.A., Munyanyiwa, H., 1998. UPb zircon age for the Umkondo dolerites, eastern Zimbabwe: $1.1 \mathrm{Ga}$ large igneous province in southern Africa-East Antarctica and possible Rodinia correlations. Geology 26, 1143-1146.

Hanson, R.E., Crowley, J.L., Bowring, S.A., Ramezani, J., Gose, W.A., Dalziel, I.W.D., Pancake, J.A., Seidel, E.K., Blenkinsop, T.G., Mukwakwami, J., 2004. Coeval largescale magmatism in the Kalahari and Laurentian cratons during Rodinia assembly. Science 304, 1126-1129. http://dx.doi.org/10.1126/science.1096329.

Harris, C., Marsh, J.S., Duncan, A.R., Erlank, A.J., 1990. The petrogenesis of Kirwan basalts of Dronning Maud Land, Antarctica. Petrology 31, 341-369.

Helferich, S., Läufer, A.L., Henjes-Kunst, F., Kleinschmidt, G., 2004. Pan-African events in southern Kirwanveggen (western Dronning Maud Land, Antarctica) - evidence from structural geology and geochronology. Zeitschrift der deutschen geologischen Gesellschaft 154, 453-468.

Jacobs, J., Thomas, R.J., 2004. Himalayan-type indenter-escape tectonics model for the southern part of the Neoproterozoic-early Paleozoic East African-Antarctic orogen. Geology 32, 721-724. 
Jacobs, J., Fanning, C.M., Henjes-Kunst, F., Olesch, M., Paech, H., 1998. Continuation of the Mozambique belt into East Antarctica: Grenville-age metamorphism and polyphase Pan-African high-grade events in central Dronning Maud Land. Journal of Geology 106, 385-406.

Jacobs, J., Bauer, W., Fanning, C.M., 2003. Late Neoproterozoic/Early Palaeozoic events in central Dronning Maud Land and significance for the southern extension of the East African Orogen into East Antarctica. Precambrian Research 126, 27-53.

Jacobs, J., Damaske, D., Läufer, A., Estrada, S., Jokat, W., Riedel, S., Mieth, M., Ruppel, T., Lucka, A., Ehlburg, M., Clark, C., Flowerdew, M., 2012. Geodynamic Evolution of East Antarctica, GEA I + II Geological expedition to Sør Rondane and adjacent areas. Eastern Dronning Maud Land, Austral summers 2011/12 and 2011/12: SCAR Open Science Meeting, Portland (USA), 14 July 2012 - 19 July 2012.

Jokat, W., Boebel, T., König, M., Meyer, U., 2003. Timing and geometry of early Gondwana breakup. Journal of Geophysical Research 108 (B9), 2428. http://dx.doi.org/ 10.1029/2002JB001802.

Kleinschmidt, G., 2002. Geology of nunataks of Prinzregent-Luitpold-Land (Coats Land, Antarctica) and their geotectonic importance. Courier Forschungsinstitut Senckenberg 237, $1-14$.

Kleinschmidt, G., Boger, S.D., 2009. The Bertrab, Littlewood and Moltke Nunataks of PrinzRegent-Luitpold-Land (Coats Land): enigma of East Antarctic Geology. Polarforschung 78 (3), 95-104

Kleinschmidt, G., Henjes-Kunst, F., Tessensohn, F., 2001. Nappe tectonics in the central Shackleton Range, Antarctica. Zeitschrift der deutschen geologischen Gesellschaft $152,227-248$.

König, M., Jokat, W., 2006. The Mesozoic breakup of the Weddell Sea. Journal of Geophysical Research 111, B12102. http://dx.doi.org/10.1029/2005JB004035.

Leinweber, V.T., Jokat, W., 2012. The Jurassic history of the Africa-Antarctica corridor new constraints from magnetic data on the conjugate continental margins. Tectonophysics 530, 87-101. http://dx.doi.org/10.1016/j.tecto.2011.11.008.

Lindeque, A., de Wit, M., Ryberg, T., Weber, M., Chevallier, L., 2011. Deep crustal profile across the southern Karoo Basin and Beattie Magnetic Anomaly, South Africa: Integrated interpretation with tectonic implications. South African Journal of Geology 114 (3-4), 265-292. http://dx.doi.org/10.2113/gssajg.114.3-4.265.

Loewy, S.L., Dalziel, IW.D. Pisarevsky, S., Connelly, JN., Tait, J., Hanson, R.E., Bullen, D, 2011. Coats Land crustal block, East Antarctica: A tectonic tracer for Laurentia? Geology 39, 859-862. http://dx.doi.org/10.1130/G32029.1.

Martin, A.K., Hartnady, C.J.H., 1986. Plate tectonic development of the South West Indian Ocean: A revised reconstruction of East Antarctica and Africa. Journal of Geophysical Research 91, 4767-4786.

Maus, S., Sazonova, T., Hemant, K., Fairhead, J.D., Ravat, D., 2007. National Geophysical Data Center candidate for the World Digital Magnetic Anomaly Map. Geochemistry, Geophysics, Geosystems 8, Q06017. http://dx.doi.org/10.1029/2007GC001643.

McLean, M.A., Wilson, C.J.L., Boger, S.D., Betts, P.G., Rawling, T.J., Damaske, D., 2009. Basement interpretations from airborne magnetic and gravity data over the Lambert Rift region of East Antarctica. Journal of Geophysical Research 114, B06101. http://dx.doi.org/10.1029/2008JB005650.

Meert, J.G., 2003. A synopsis of events related to the assembly of eastern Gondwana. Tectonophysics 362, 1-40.

Moores, E.M., 1991. Southwest U.S-East Antarctica (SWEAT) connection: A hypothesis. Geology 19, 425-428. http://dx.doi.org/10.1130/0091-7613(1991) 019<0425:SUSEAS>2.3.CO;2.

Moyes, A.B., Barton, J.M., Groenewald, P.W., 1993. Late Proterozoic to Early Palaeozoic tectonism in Dronning Maud Land, Antarctica: supercontinental fragmentation and amalgamation. Journal of the Geological Society 150, 833-842.
Perritt, S.H., Watkeys, M.K., 2003. Implications of late Pan-African shearing in western Dronning Maud Land, Antarctica. In: Storti, F., Holdsworth, R.E., Salvini, F. (Eds.) Intraplate strike- slip Deformation Belts: Geological Society London Special Publications, 210, pp. 135-143. http://dx.doi.org/10.1144/GSL.SP.2003.210.01.08.

Riedel, S., Jacobs, J., Jokat, W., 2013. Aeromagnetics of Dronning Maud Land and geodynamic implications for Rodinia and Gondwana reconstructions. Tectonophysics $585,161-171$

Ruppel, A.S., 2012. Structural Evolution of the Main Shear Zone in Sør Rondane, East Antarctica. University of Bremen, Germany 9 (Master Thesis).

Satish-Kumar, M., Hokada, T., Kawakami, T., Dunkley, D.J., 2008. Geosciences research in East Antarctica (08E-608E): present status and future perspectives. From: In: SatishKumar, M., Motoyoshi, Y., Osanai, Y., Hiroi, Y., Shiraishi, K. (Eds.), Geodynamic Evolution of East Antarctica: A Key to the East-West Gondwana Connection: Geological Society London, Special Publications, 308, pp. 1-20. http://dx.doi.org/10.1144/SP308.1.

Schlüter J, Estrada, S., Lisker, F, Läufer, A., Kühn, R., Nitzsche, K.N., Spiegel, C., 2011. First petrographical description of rock occurrences in the Steingarden Area, Dronning Maud Land, East Antarctica. Polarforschung 80 (3), 161-172.

Shackleton, R.M., 1996. The final collision zone between East and West Gondwana: where is it? Pergamon 23, 271-287.

Shepherd, T., Bamber, J.J., Ferraccioli, F., 2006. Subglacial geology in Coats Land, East Antarctica, revealed by airborne magnetics and radar sounding. Earth and Planetary Science Letters $244(1-2), 323-335$.

Shiraishi, K., Ellis, D.J., Hiroi, Y., Fanning, C.M., Motoyoshi, Y., Nakai, Y., 1994. Cambrian orogenic belt in East Antarctica and Sri Lanka: implications for Gondwana assembly. Journal of Geology 102, 47-65.

Shiraishi, K., Dunkley, D.J., Hokada, T., Fanning, C.M., Kagami, H., Hamamoto, T., 2008. Geochronological constraints on the Late Proterozoic to Cambrian crustal evolution of eastern Dronning Maud Land, East Antarctica: a synthesis of SHRIMP U-Pb age and Nd model age data. In: Satish-Kumar, M., Motoyoshi, Y., Osanai, Y., Hiroi, Y., Shiraishi, K. (Eds.), Geodynamic Evolution of East Antarctica: A key to the East-West Gondwana connection: Geological Society London Special Publications, 308, pp. 21-67.

Studinger, M., Miller, H., 1999. Crustal structure of the Filchner-Ronne Shelf and Coats Land, Antarctica, from gravity and magnetic data; implications for the breakup of Gondwana. Journal of Geophysical Research 104, 20,379-20,394. http://dx.doi.org/ 10.1029/1999JB900117.

Talarico, F., Kleinschmidt, G., 2009. The Antarctic continent in Gondwanaland: A tectonic review and potential research targets for future investigations. In: Florindo F., Siegert, M. (Eds.), Antarctic climate evolution: Developments in Earth \& Environmental Science, 8, pp. 257-308.

Talarico, F., Kleinschmidt, G., Henjes-Kunst, F., 1999. An ophiolitic complex in the northern Shackleton Range, Antarctica. Terra Antarctica 6, 293-315.

Tessensohn, F., Kleinschmidt, G., Talarico, F., Buggisch, W., Brommer, A., Henjes-Kunst, F., Kroner, U., Millar, I.L., Zeh, A., 1999. Ross-age amalgamation of East and West Gondwana: Evidence from the Shackleton Range, East Antarctica. Terra Antarctica 6, 317-325.

Wolmarans, L.G., Kent, L.E., 1982. Geological investigations in western Dronning Maud Land, Antarctica-a synthesis. South African Journal of Antarctic Research (Supplement 2), 14-53.

Zeh, A., Millar, I.L., Horstwood, S.A., 2004. Polymetamorphism in the NE Shackleton Range, Antarctica: constraints from Petrology and U-Pb, Sm-Nd, Rb-Sr TIMS and in situ U-Pb LA-PIMMS dating. Journal of Petrology 45, 949-973. 